\title{
Comparative Study of Fish Silage Prepared from Fish Market Waste by Using Different Techniques
}

\author{
Nikhil D. Palkar*, J.M. Koli, S.B. Patange, S.T. Sharangdhar, \\ R.K. Sadavarte and A.E. Sonavane \\ College of Fisheries Shirgaon, Ratnagiri, Maharashtra, Dr. B.S. Konkan \\ Krishi Vidhypeeth, Dapoli, India \\ *Corresponding author
}

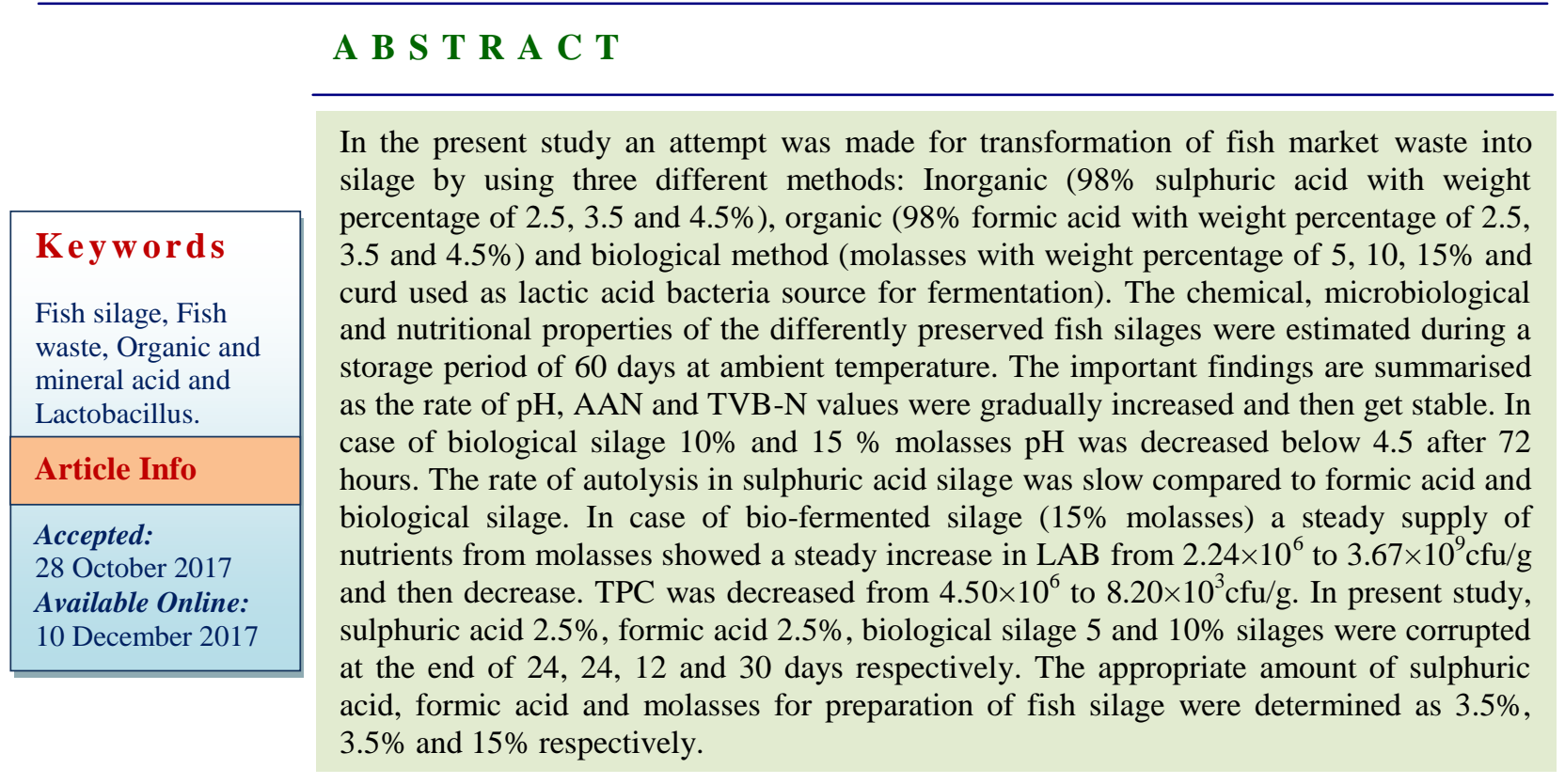

\section{Introduction}

Fish is today considered as the most promising inexpensive alternative source of animal protein consumed by the man and it offers relatively high amount of essential amino acid, minerals and fatty acids as compared to live stock (Huisman et al., 1989). In 2015, total marine fish landing of Maharashtra was 2.65 lakh tonnes (CMFRI, 2015). An average of $30 \%$ of the catch was sold locally as a fresh fish, 20-30\% was used in canning industry and the rest was used mainly in fish meal production (Anon, 1999). In the tropical countries, every efforts must be made to preserve fish for human consumption, but seasonal variation in catch, transport difficulties, inadequate processing facilities etc., resulted in the important quantities of fish has been wasted (Disney et al.,1977).

During, sea foods processing large amount of fish waste and deteriorated whole fishes are 
discarded daily in the fish markets (Faid et al., 1996). Fish waste, includes frames and rests from trimming, guts, skins, fats, viscera, eggs, heads, breasts, scales and deteriorated filets. A fish contain $45 \%$ flesh, 24-27\% head, $12 \%$ skeleton, $3 \%$ skin, $4 \%$ cut off and $12 \%$ viscera including eggs, milts and liver of its total body weight (DOF, 2013). These wastes are a potential source of pollution and contamination of the environment, as they degrade rapidly in warm temperatures. If it is not appropriately stored or managed, it creates aesthetic problems and strong odours due to bacterial decomposition. But on the other hand, they contain relatively high amount of nutrients such as protein, fat and minerals (Djazuli et al., 2007) which is easily available in low cost. So that, there is need for developing new methods for biotransformation of this fishery waste into animal feed to reduce aqua production cost.

Fish meal production is most commonly used method to recover the nutrient loss in discarding the fish processing by products and it was used as animal feed. If there is absence of any fish meal plant in the area due to restriction on fish meal production to avoid fish odours, no transport facility is available towards the nearest fish meal plant and increasing price of fish meal due diminishing fish stock, then one has to look for alternate process

The best alternative way of utilizing fish waste material is the production of fish silage which does not release any off odour during preparation (Pagarkar et al., 2005).The product has a good nutritive quality and can be sufficient for animal feeding. This procedure is safe, cost effective, eco-friendly and has a good nutritive quality which can be adequate for animal feeding (Hanafy and Ibrahim, 2004). Fish silage preparation usually depends on the locally available raw materials and conditions (Hasan, 2003).
Fish silage is defined as a liquid product produced from the whole fish or parts of it, to which acids, enzymes or lactic acid-producing bacteria are added, with the liquefaction of the mass provoked by the action of enzymes from the fish (FAO, 2007). Fish silage is the liquefied product rich in protein and free amino acids (Martin, 1996). The liquefaction of fish mass carried out by enzymes already present in fish (Tatterson and Windsor, 1974). This is obtain by action of the naturally occurring enzymes presence in the whole fish, fish minced or fish offal. The enzymes, mainly from the digestive organ, break down protein into smaller soluble unit and the acid helps to speed up their enzyme activity while preventing bacterial spoilage (Al-Abri et al., 2014).

Depending on the process employed in the preservation of fish waste, fish silage can be categorised in two methods, viz. acid silage and bio-fermented silage (Raa and Gildberg, 1982). Acid silage is produced by mixing fish waste with inorganic (sulphuric acid, hydrochloric acid) and organic acid (formic acid, propionic acid) or mixture of both organic and inorganic acid, while biofermented silage is obtain by adding fermentable sugar to fish biomass. Fermentation is carried out by lactic acid bacteria (LAB) which are already present in a fish mass or added externally for successful fermentation. In view of above facts, the present research work was to study different methods of producing high quality of fish silage.

\section{Materials and Methods}

Fish market wastes were procured from fish market of Ratnagiri. The fish mainly consisted of heads, tails, gills, fins and visceras of Sardine (Sardinella fimbriata, Sardinella longiceps), Mackerel (Rastrelliger kanagurta), Tuna (Euthynnus affinis, Auxis 
thazard), Pink perch (Nemipterus japonicus), Ribbon fish (Trichiurus lepturus, Lepturocanthus savala), Bombay duck (Harpadon nehereus), Seer fish (Scomberomorus guttatus, Scomberomorus commerson), Mullet (Mugil cephalus). The collected fish wastes were washed with potable water and stored at $-20{ }^{\circ} \mathrm{C}$ until further used.

The fish waste was thawed, washed, and grinded into paste using mixer for preparation of different types of silage.

Silage production using mineral acid (Mousavi et al., 2013)

$1.5 \mathrm{~kg}$ of minced fish waste was poured in three plastic containers (each container containing 500 gram of fish waste) and $98 \%$ sulphuric acid with weight percentages of 2.5 , 3.5 , and $4.5 \%(\mathrm{v} / \mathrm{w})$ and $65 \mathrm{mg}$ of Butylated Hydroxy Toluene (BHT) were added to each sample. The mixture was stirred regularly with sterile glass rod to ensure through mixing and inhibit growth of mould on the surface. Samples were kept at room temperature $\left(28^{\circ} \mathrm{C}\right.$ to $\left.32^{\circ} \mathrm{C}\right)$ for 60 days and stirred every 8 hours. $\mathrm{pH}$ changes were measured by $\mathrm{pH}$ meter and recorded until it reached a stable level.

Silage production using organic acid (Mousavi et al., 2013)

$1.5 \mathrm{~kg}$ of minced fish waste was poured in three plastic containers (each container containing 500 gram of fish waste) and $98 \%$ formic acid with weight percentages of 2.5 , 3.5 , and $4.5 \%(\mathrm{v} / \mathrm{w})$ and $65 \mathrm{mg}$ of Butylated Hydroxyl Toluene (BHT) were added to each sample. The mixture was stirred regularly with sterile glass rod to ensure through mixing and inhibit growth of mould on the surface. Samples were kept in room temperature $\left(28^{\circ} \mathrm{C}\right.$ to $\left.32^{\circ} \mathrm{C}\right)$ for 60 days and stirred every 8 hours. $\mathrm{pH}$ changes were measured by using $\mathrm{pH}$ meter and recorded until it reached a stable level.

\section{Silage production by biological method using Curd (Palekar, 2009)}

$1.5 \mathrm{~kg}$ of minced fish waste was poured in three plastic containers (500 grams in each). Then, sugar cane molasses and water was added to each container with weight percentages of $5 \%, 10 \%, 15 \%(\mathrm{v} / \mathrm{w})$ and $30 \%$ $(\mathrm{v} / \mathrm{w})$ respectively. $65 \mathrm{mg}$ of butylated hydroxytoluene (BHT) were added to each sample. The mixture was stirred using a sterile glass rod to ensure through proper mixing. After these samples were heated in water bath for 15 minutes at $90{ }^{\circ} \mathrm{C}$ and then cooled at a room temperature. Then curd (starter culture) with a weight percentage of $10 \%(\mathrm{w} / \mathrm{w})$ was added to them. Mix the samples thoroughly and stored in airtight plastic container. $\mathrm{pH}$ changes were measured by $\mathrm{pH}$ meter and recorded until it reached a stable level.

\section{Preparation of starter culture}

Curd was prepared fresh from boiled and cooled milk and kept for overnight. Lactic acid bacterial (LAB) count of curd was estimated by pour plating technique on MRS agar and Lactic Acid Bacteria (LAB) count of $4.20 \times 10^{6} \mathrm{cfu} / \mathrm{gram}$ used for preparation of biological silage.

\section{Chemical analysis}

Chemical analysis of raw materials and silages were analysed by measuring moisture, protein, fat, ash content and $\mathrm{pH}$ according to AOAC official methods (AOAC, 2005). AAN measured according to Benjakul and Morrissey (1997), T-VBN measured according to Beatty and Gibbons (1937) and TPC according to APHA (1992). 


\section{Statistical analysis}

The data were analysed to test significant difference by applying analysis of variances (ANOVA) tools available in MS-Excel 2010. The significant differences were tested by $5 \%$ level of significances and are mentioned as $p$ $<0.05$ for significances difference (Snedecor and Cocharn, 1967).

\section{Results and Discussion}

\section{Biochemical and microbiological analysis of fish market waste}

The biochemical and microbiological characteristics of fish waste were analysed during the initial stage of present work. The fish waste used for the present work was having acceptable fishy smell and appearance. Proximate composition of fish waste on wet basis is shown in Table 1. Fish waste contained moisture $77.09 \pm 0.14 \%$, crude protein $15.20 \pm 0.15 \%$, fat $4.03 \pm 0.07 \%$ and ash $3.30 \pm 0.11 \%$.On a similar line the biochemical quality of fish market waste contained $79.47 \%$ of moisture, $15.78 \%$ of protein, $2.13 \%$ of lipid and $2.32 \%$ of ash in fish waste reported by Palekar (2009). Similar results also given by Abowei and Tawari (2011), Gullu et al., (2015), Tatterson and Windser (1974), Hasan and heath (1987), Ozyurt et al., (2015).The variation noted in proximate composition may be due to the age, sex, body weight, seasonal, feeding aspects of fish material.

The $\mathrm{pH}, \alpha$ - amino nitrogen, TVB-N and TPC of fish waste were $6.8 \pm 0.49,10.64 \pm 0.13$

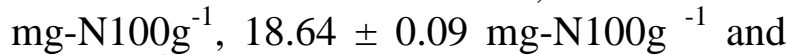
$5.1 \times 10^{6} \mathrm{cfu} / \mathrm{g}$ respectively. Similar results were depicted by Palekar (2009) had found 7.16 of $\mathrm{pH}, 18.68 \mathrm{mg}-\mathrm{N} 100 \mathrm{~g}^{-1}$ of TVB-N, $32.11 \mathrm{mg}-\mathrm{N} 100 \mathrm{~g}^{-1}$ of $\alpha$ amino nitrogen (AAN) and $6.7 \times 10^{6} \mathrm{cfu} / \mathrm{g}$ TPC in pink perch raw material.

\section{Biochemical and microbiological changes during storage}

\section{pH}

\section{Sulphuric acid}

In present study the $\mathrm{pH}$ of different treatment of sulphuric acid silage A1, A2, A3 (sulphuric acid $2.5 \%, 3.5 \%$ and $4.5 \%$ respectively) were 2.97, 1.94, and 1.33 initially. In treatment A1 (sulphuric acid $2.5 \%$ ) $\mathrm{pH}$ was reached up to 4.62 at the end of $24^{\text {th }}$ day. Then sample was corrupted. It may be due to quantity of acid used was insufficient to prevent the activity of putrefactive bacteria. In Treatments A2 and A3 (Sulphuric acid 3.5\% and $4.5 \%$ ) pH was stable at 2.66 and 1.92 at the end of $30^{\text {th }}$ day respectively. There was no increased in $\mathrm{pH}$ at the end of $60^{\text {th }}$ days of storage. Similar trends were observed by Mousavi et al., (2013) reported that when $98 \%$ sulphuric acid with weight percentage $2.5 \%$ used sample got musty after 20 days. In sulphuric acid with weight $3.5 \%$ and $4.5 \%, \mathrm{pH}$ of samples reached a stable level at 2.58 and 1.94 respectively after 40 days (Fig. 1).

\section{Formic acid}

In present study the initial $\mathrm{pH}$ of different treatments of Formic acid silages viz. B1, B2, B3 (Formic acid 2.5\%, 3.5\% and 4.5\%) were $3.43,3.14$, and 2.73 respectively. In, Treatment B1 (Formic acid 2.5\%), pH was increased from 3.43 to 4.64 at the end of $24^{\text {th }}$ day. Then sample was corrupted because of amount of acid used was incapable for arrest the action of putrefactive bacteria. $\mathrm{pH}$ of treatments B2 and B3 (Formic acid 3.5\% and $4.5 \%$ ) were stable at 3.65 and 3.41 at the end of $24^{\text {th }}$ day respectively. Mousavi et al., (2013) investigated similar trends, when $98 \%$ Formic acid with weight percentage 2.5\% used sample got musty after 6 days at $\mathrm{pH}$ 3.61. Formic acid with weight $3.5 \%$ and $4.5 \%$ 
used $\mathrm{pH}$ of sample reached a stable level at 3.88 and 3.61 respectively after 56 and 66 days (Fig. 2)

\section{Biological silage}

The initial $\mathrm{pH}$ of Biological silage prepared using different percentages of molasses viz. C1, C2 and C3 (Biological silage 5\%, $10 \%$ and $15 \%$ ) were $6.85,6.56$ and 6.75 respectively. During fermentation fall in $\mathrm{pH}$ was noticed in all the treatments. In treatment $\mathrm{C} 1$ (Biological silage 5\%), $\mathrm{pH}$ was decreased from 6.85 to 5.24 at the end of $12^{\text {th }}$ day.Then sample was corrupted. It occurs due tofive percent molasses was inadequate to produce good fermentation. Similar observations were reported by Kompiang et al., (1979), they observed Fish: molasses ratio of 100:5 gave silage stable only up to few days. Generally, fish is a poor source of carbohydrates. It needed for to ferment and produce lactic acid in the silage. Production of organic acid helps to reduction of $\mathrm{pH}$ value in fermented silage and prevents the growth of spoilage organism. If sufficient carbohydrate is not present in the medium, required levels of acid will not be produced, as results of putrefying bacteria increased. In, treatments C3 (Biological silage $15 \%) \mathrm{pH}$ were decrease below 4.4 within 72 hours and then increase and stable at 4.30 at the end of $24^{\text {th }}$ days respectively (Fig. 3).

Similar trends were observed by James (1966) that precooked silage showed rapid fermentation and reached a $\mathrm{pH}$ of 4.4 within 72 hours. Treatment C2 (Biological silage $10 \%$ ) got putrefied at the end of $30^{\text {th }}$ day. The last measured $\mathrm{pH}$ was 4.65. Similar results were scrutinized by Neethiselvan et al., (2002), Palekar (2009). Recommended pH value for preserved fish silage should be below 4.5 reported by Epse and Lied (1999).The slight fluctuation in $\mathrm{pH}$ during the storage period in all silages was probably caused by the dissolving of fish skin, bones and scales (Ozyurt et al.,2015). The results indicate that $15 \%$ molasses was sufficient to produce good fermentation.

\section{Alpha Amino Nitrogen (AAN)}

Digestion of protein in the silage as determined by liquefaction and production of NPN and NH3. The rapid production of NPN was observed within 30 days of storage.

\section{Sulphuric acid}

The AAN content of different treatments of sulphuric acid silage viz. A1, A2 and A3 (sulphuric acid $2.5 \%, 3.5 \%$ and $4.5 \%$ ) were 25.27, 14.80, $11.89 \mathrm{mg}-\mathrm{N} 100 \mathrm{~g}-{ }^{1}$ initially and it reached up to 47.71 and $45.24 \mathrm{mg}-\mathrm{N} 100 \mathrm{~g}-1$ at the end of $30^{\text {th }}$ day in treatments $\mathrm{A} 2$ and $\mathrm{A} 3$ (sulphuric acid 3.5 and $4.5 \%$ ) respectively (shown in Fig. 4). There was no increase in AAN even after $30^{\text {th }}$ day of storage. Treatment A3 (Sulphuric acid $4.5 \%$ ) showed slow rate of autolysis compared to treatments A1 and A2 (sulphuric acid 2.5 and 3.5\%). This is occurs due to difference in the $\mathrm{pH}$ produced by acids. At high acid concentration of acid shown low $\mathrm{pH}$ and inhibitory to proteolysis. When mineral and organic acid are used for production of fish silage the rate of liquefaction of protein is different. At $\mathrm{pH} 3$ the rate of autolysis and yield of soluble matter was less (Raa and Gildberg, 1982).

Raghunath and Mc Curdy (1990) reported that at $\mathrm{pH} 3$ both endopeptidases and exopeptidases were active, the silage quickly breaking down the protein nitrogen to amino nitrogen. But at $\mathrm{pH} 2$ only acid endopeptidase and a weak exopeptidase activity were detected, thus slowing the rate of autolysis. Stone and hardy (1986) reported that acid stabilised silage (sulphur $2.45 \%$ ) of pacific whiting shown no increase in levels of amino nitrogen even after 42 days of storage indicating the absence of autolysis. 


\section{Formic acid}

The AAN content of different treatments of Formic acid silage: B1, B2 and B3 (Formic acid $2.5 \%, 3.5 \%$ and $4.5 \%$ ) were 26.97 , $16.31,14.76 \mathrm{mg}-\mathrm{N} 100 \mathrm{~g}^{-1}$ initially and it

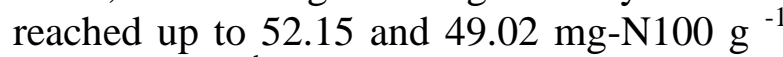
at the end $24^{\text {th }}$ day in treatments B2 and B3 (Formic acid 3.5 and $4.5 \%$ ) respectively shown in Figure 5.

There was no increase in AAN even after $24^{\text {th }}$ day of storage. Babu et al., (2005) reported maximum alpha amino nitrogen value (as \% of $\mathrm{TN}$ ) was lower in $2.5 \%$ acid silage $(21.21 \%$ of $\mathrm{TN})$ than in $3 \%$ acid Silage (24.33\% of TN) and $2 \%$ Acid silage $(27.30 \%$ of TN). Haaland and Njaa (1989) reported that when acid addition was too low $\mathrm{pH}$ increase during storage, resulting in much higher production of ammonia. Palekar (2009) observed AAN of formic acid was $39.76 \mathrm{mg}-\mathrm{N} 100 \mathrm{~g}^{-1}$ initially which increased up to $272.69 \mathrm{mg}-\mathrm{N} 100 \mathrm{~g}^{-1}$ at the end of $90^{\text {th }}$ day.

\section{Biological silage}

Different treatments of Biological silage viz.C1, C2 and C3 (Biological silage 5\%, 10 $\%$ and $15 \%$ ) contained initial AAN were $16.61,14.28$ and $13.34 \mathrm{mg}-\mathrm{N} 100 \mathrm{~g}^{-1}$ which increased up to 34.92 and $37.35 \mathrm{mg}-\mathrm{N} 100 \mathrm{~g}^{-1}$ at the end $24^{\text {th }}$ day in treatments $\mathrm{C} 2$ and $\mathrm{C} 3$ (biological 10\% and $15 \%$ ) respectively.

There was no increase in AAN even after $24^{\text {th }}$ day of storage in treatments $\mathrm{C} 2$ and $\mathrm{C} 3$ (biological silage $10 \%$ and 15\%) respectively. In the present study, the value of protein solubilisation was found to be lower in biological silage compared to acidified silage. Similar observation was detected by Dapkeevicius et al., (1998). Ozyurt et al., (2015) depicted similar results during fermentation of fish silage that AAN was $0.07 \mathrm{~g} / 100 \mathrm{~g}$ initially increased up to 0.69 $\mathrm{g} / 100 \mathrm{~g}$ at the end of 60 days. Palekar (2009) described AAN in biological silage was increase from $36.67 \mathrm{mg} \mathrm{N} 100 \mathrm{~g}^{-1}$ to $157.00 \mathrm{mg}$ $\mathrm{N} 100 \mathrm{~g}^{-1}$ at the end of $90^{\text {th }}$ day of storage (Fig. $6)$.

\section{Total Volatile base Nitrogen (TVB-N)}

In most of the countries, total volatile nitrogen is used as quality criterion for fish silage. TVN consists mainly of trimethylamine (TMA) and ammonia $\mathrm{NH}_{3}$. TMA originates from bacterial decomposition of trimethylamineoxide (TMAO) and analysis for it may be used as criterion of the freshness of raw materials. The acceptable limit of TVB-N is $35-40 \mathrm{mg} / 100 \mathrm{~g}$ (Connel)

\section{Sulphuric acid}

TVB-N content of Sulphuric acid treatments A1, A2 and A3 (Sulphuric acid 2.5, 3.5 and $4.5 \%$ ) were $16.85,16.99$ and $17.17 \mathrm{mg}$ $\mathrm{N} 100 \mathrm{~g}^{-1}$ initially which increased up to 27.07 , $26.29 \mathrm{mg} \mathrm{N} 100 \mathrm{~g}^{-1}$ in treatments $\mathrm{A} 2$ and $\mathrm{A} 3$ (Sulphuric acid 3.5 and $4.5 \%$ ) respectively (shown in Fig. 7).

\section{Formic acid}

TVB-N content of Formic acid treatments B1, B2, B3 (Formic acid 2.5, 3.5 and 4.5\%) were $19.79, \quad 17.13, \quad 16.99 \quad \mathrm{mg}^{-\mathrm{N} 100 \mathrm{~g}^{-1}}$ initially which increased up to $27.16,25.25 \mathrm{mg}$ $\mathrm{N} 100 \mathrm{~g}^{-1}$ in treatments B2 and B3 (Formic acid 3.5 and $4.5 \%$ ) respectively. The similar results were obtained by Haaland and Naaja (1989). According to Ahmed and Mahendrakar (1996a) reported during fermentation of fresh water fish viscera, the TVB-N values increased to $8 \%$ of the total nitrogen from initial $1.3 \%$. Tanuja et al., (2014) showed that TVB-N level in both the treatments (with and without antioxidant) were well below the limit of acceptability (35$40 \mathrm{mg} \%$ ) except on the 90th day of storage (Fig. 8). 
Fig.1 pH changes in different treatments of sulphuric acid silage during storage

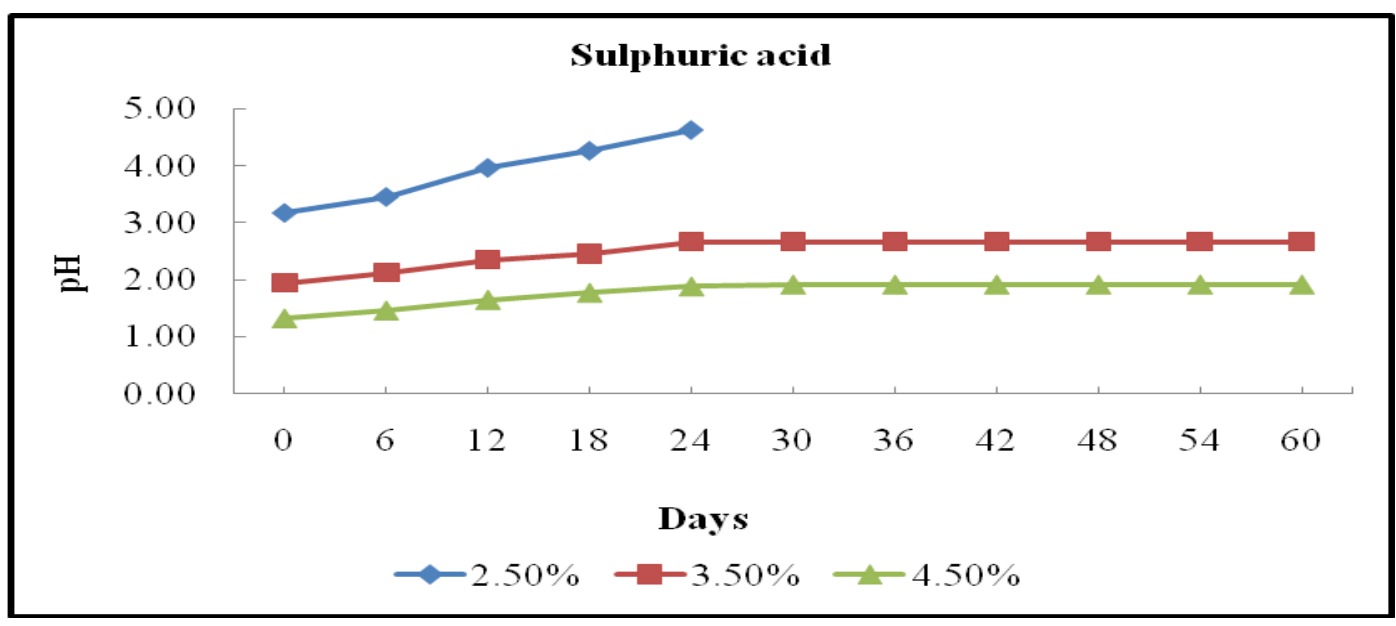

Fig.2 pH Changes in different treatments of formic acid silage during storage

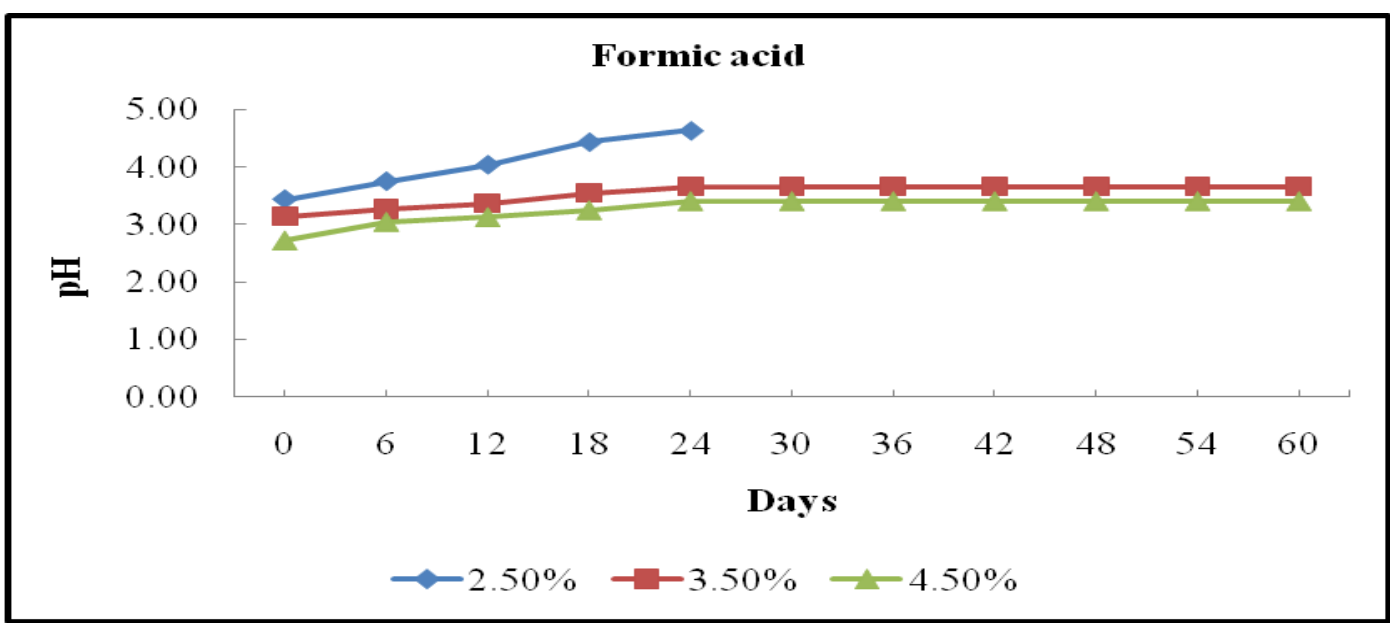

Fig.3 pH Changes in different treatments of Biological silage during storage

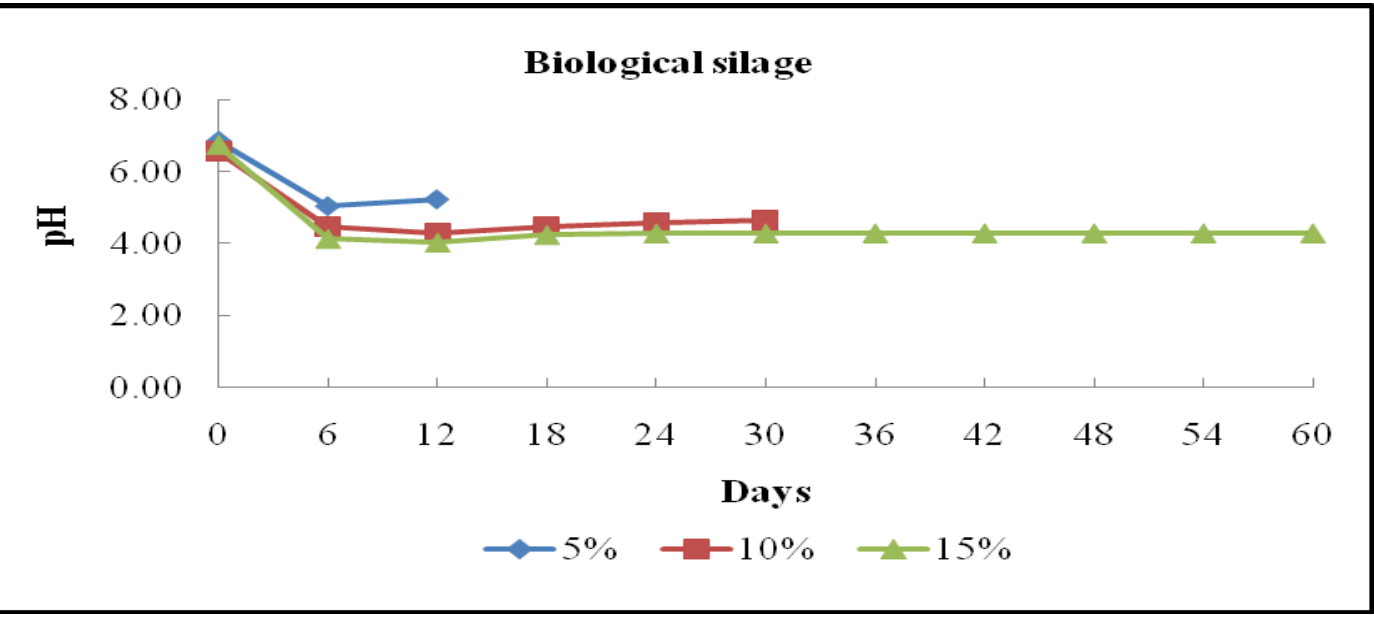


Fig.4 AAN changes in different treatments of sulphuric acid silage during storage

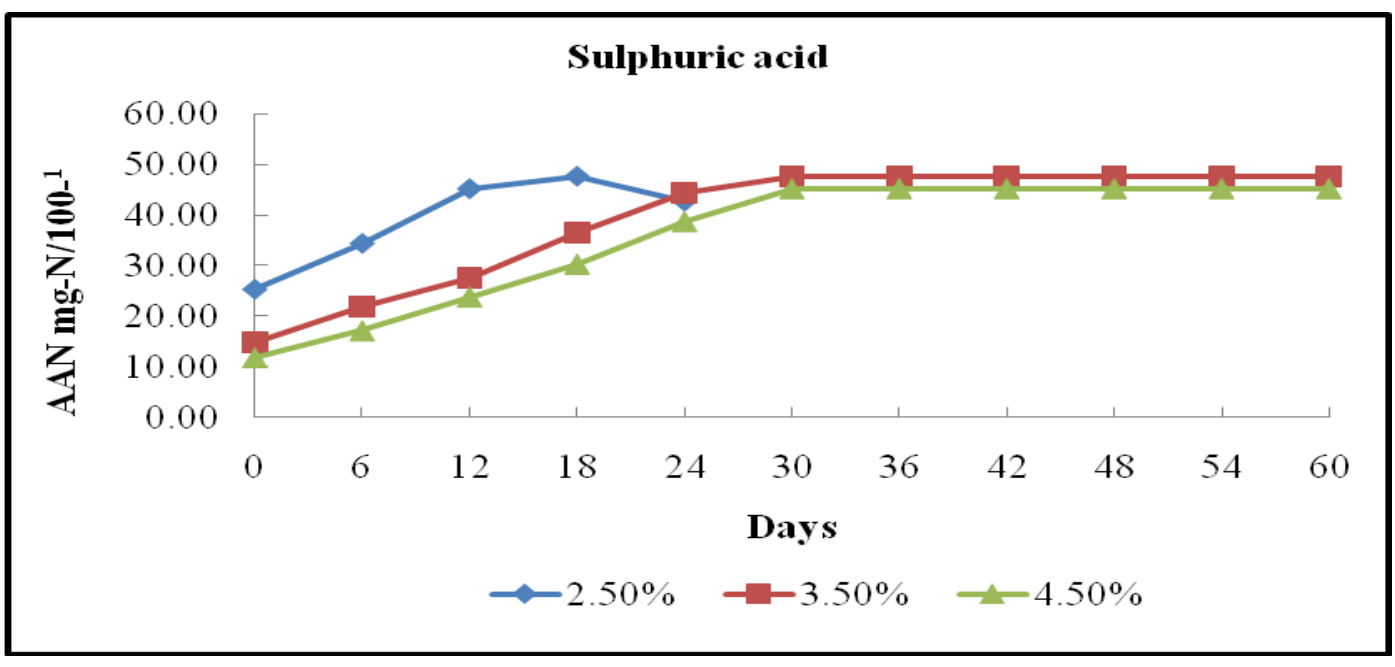

Fig.5 AAN changes in different treatments of formic acid silage during storage

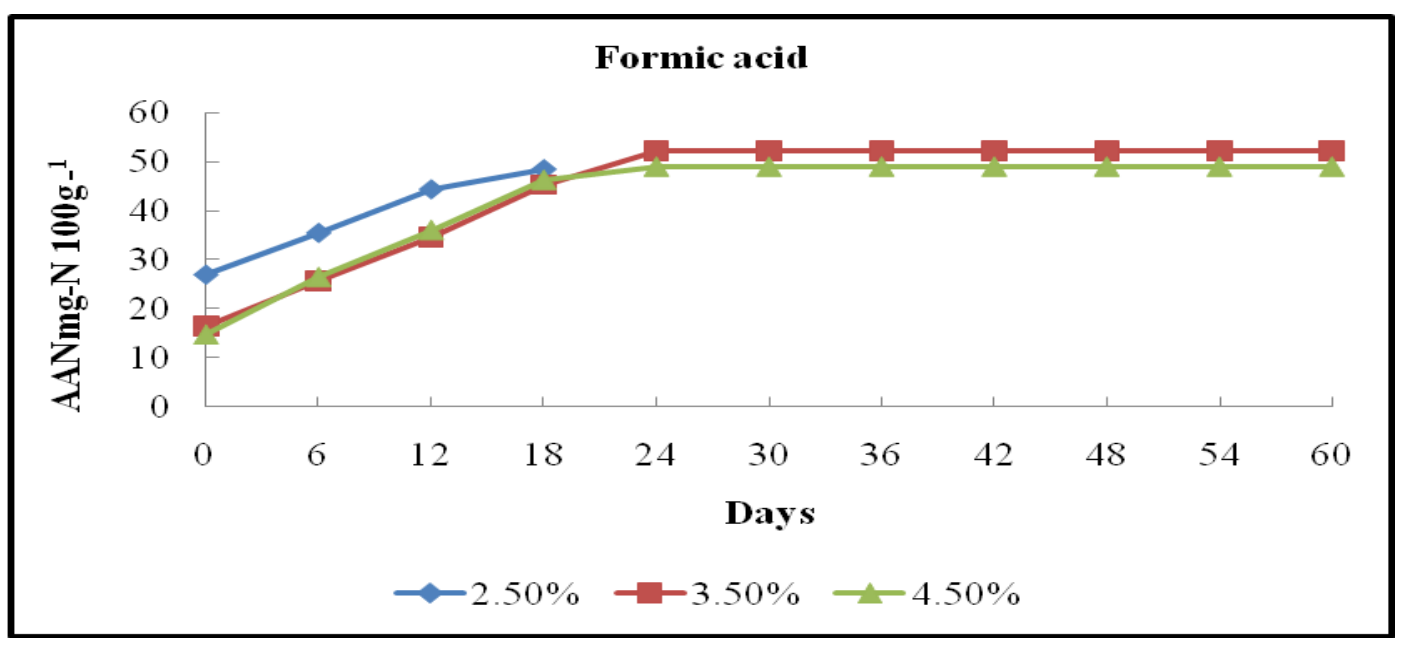

Fig.6 AAN changes in different treatments of biological silage during storage

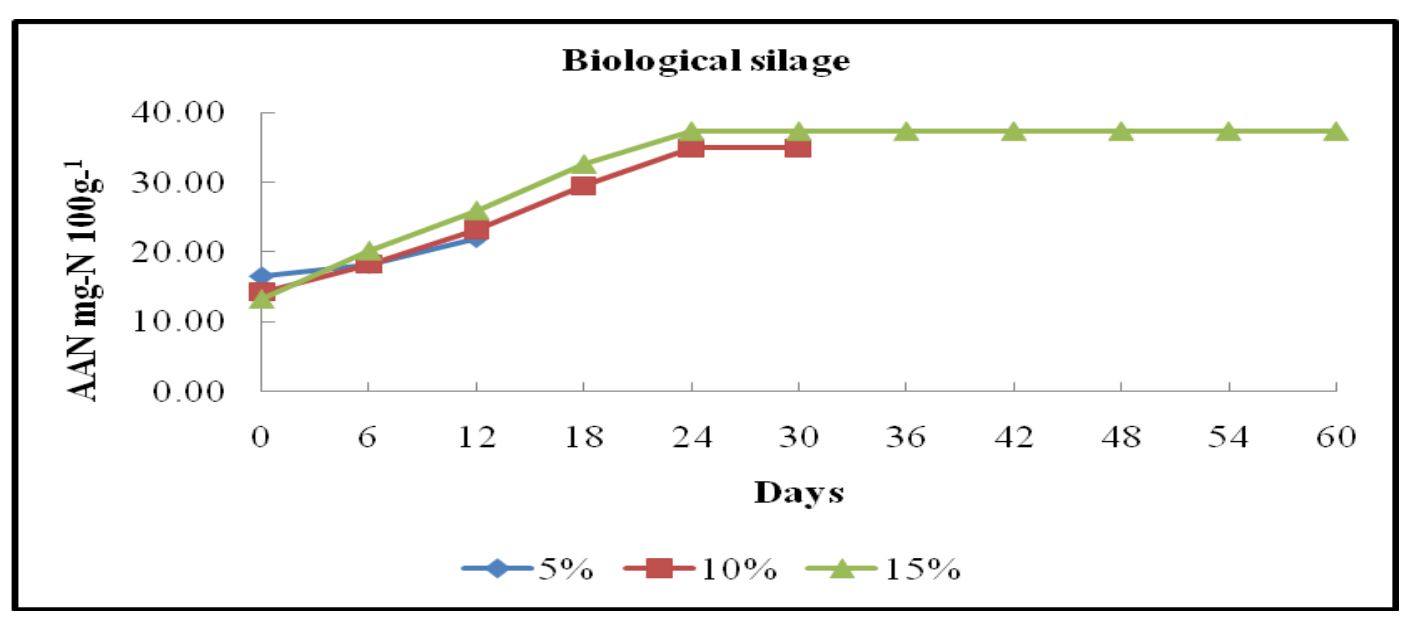


Fig.7 TVB-N changes in different treatments of Sulphuric acid silage during storage

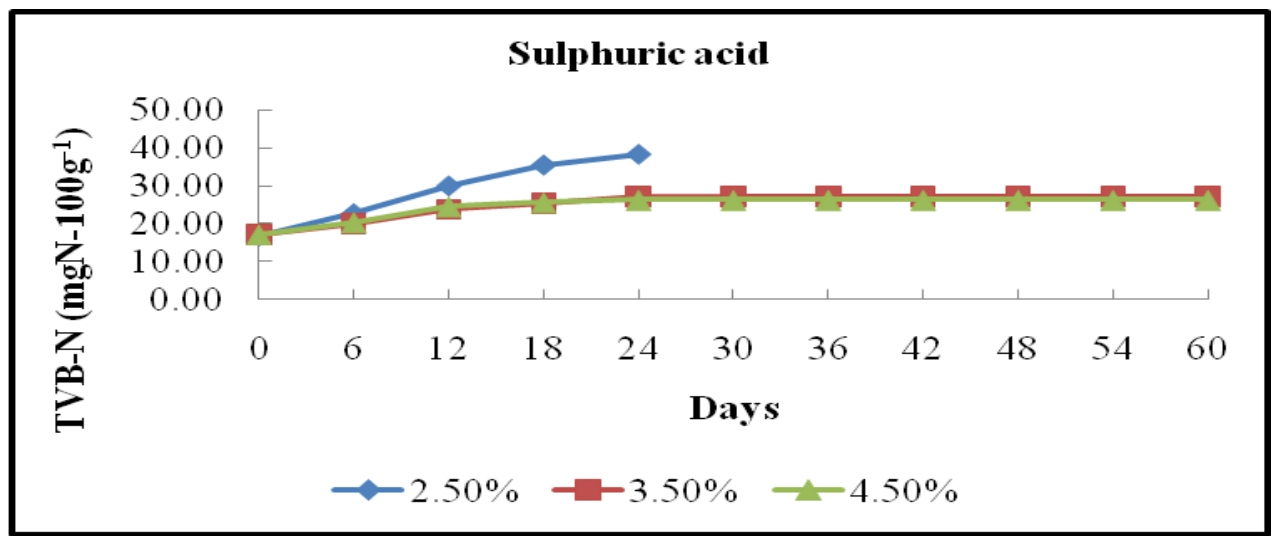

Fig.8 TVB-N changes in different treatments of formic acid silage during

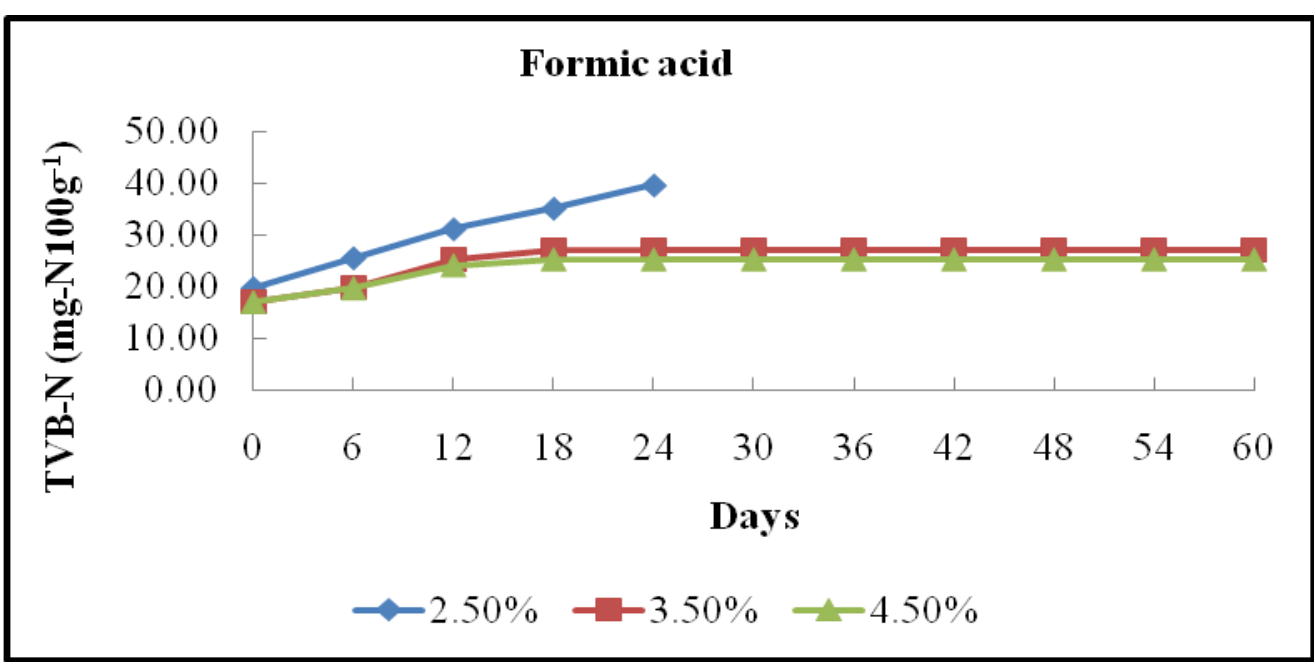

Fig.9 TVB-N changes in different treatments of biological silage during storage

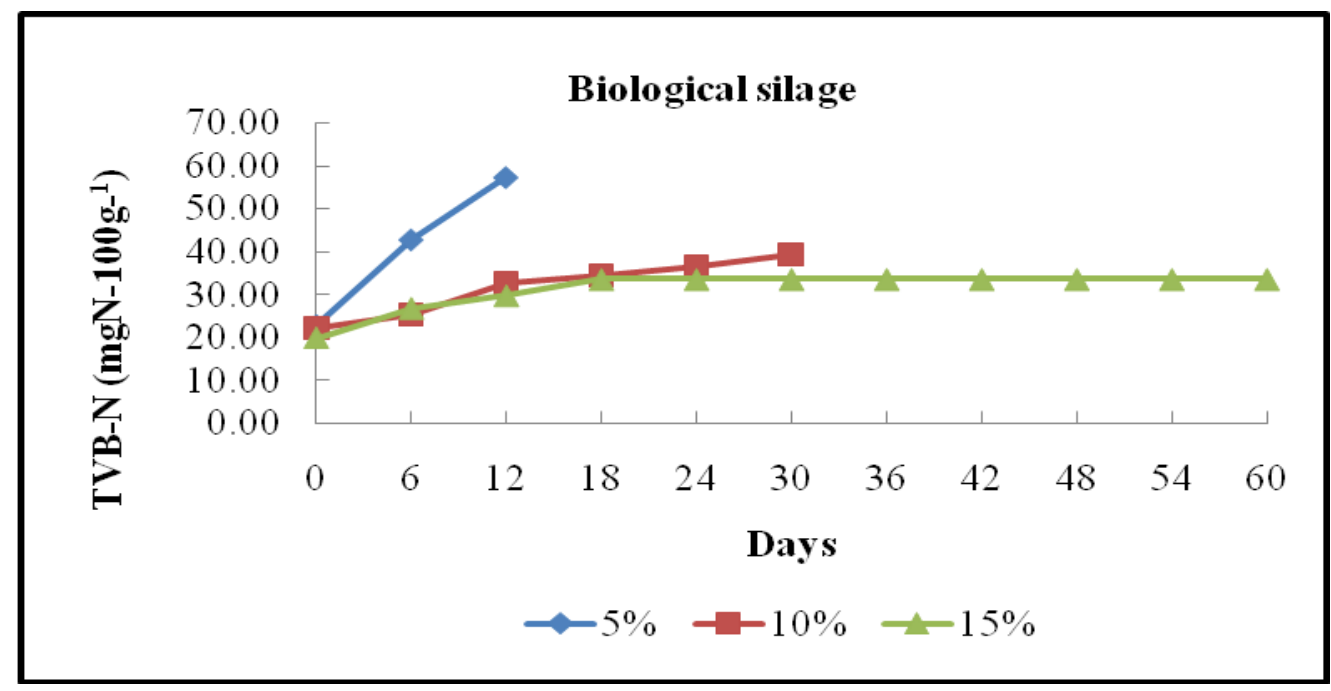


Fig.10 TPC changes in different treatments of biological silage during storage

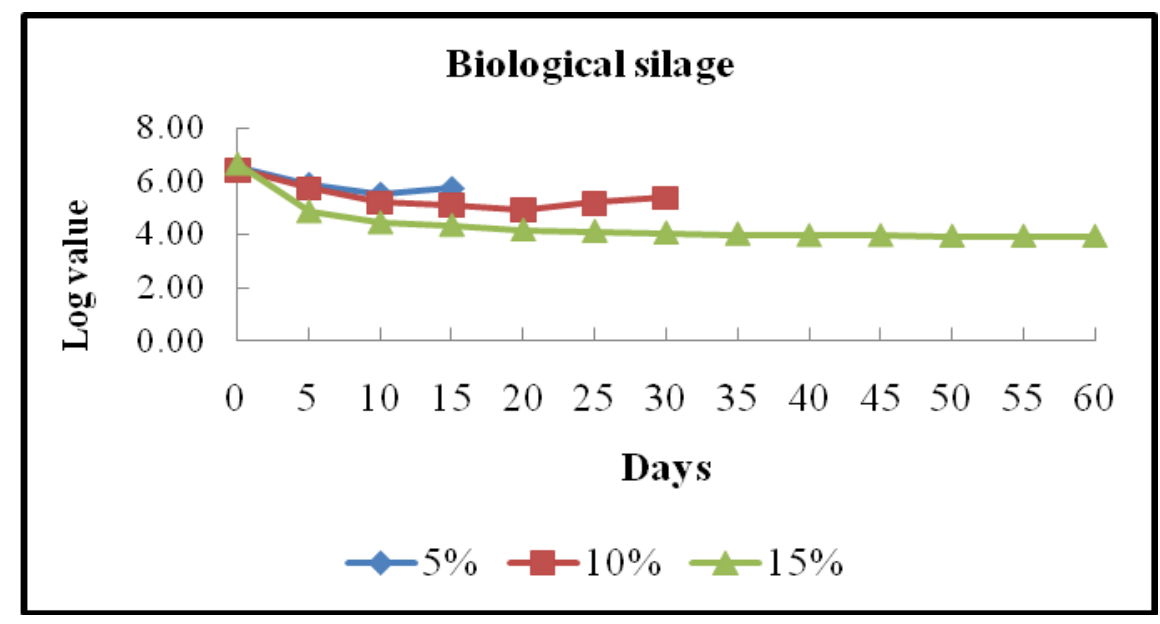

Fig.11 LAB changes in different treatments of biological silage during storage

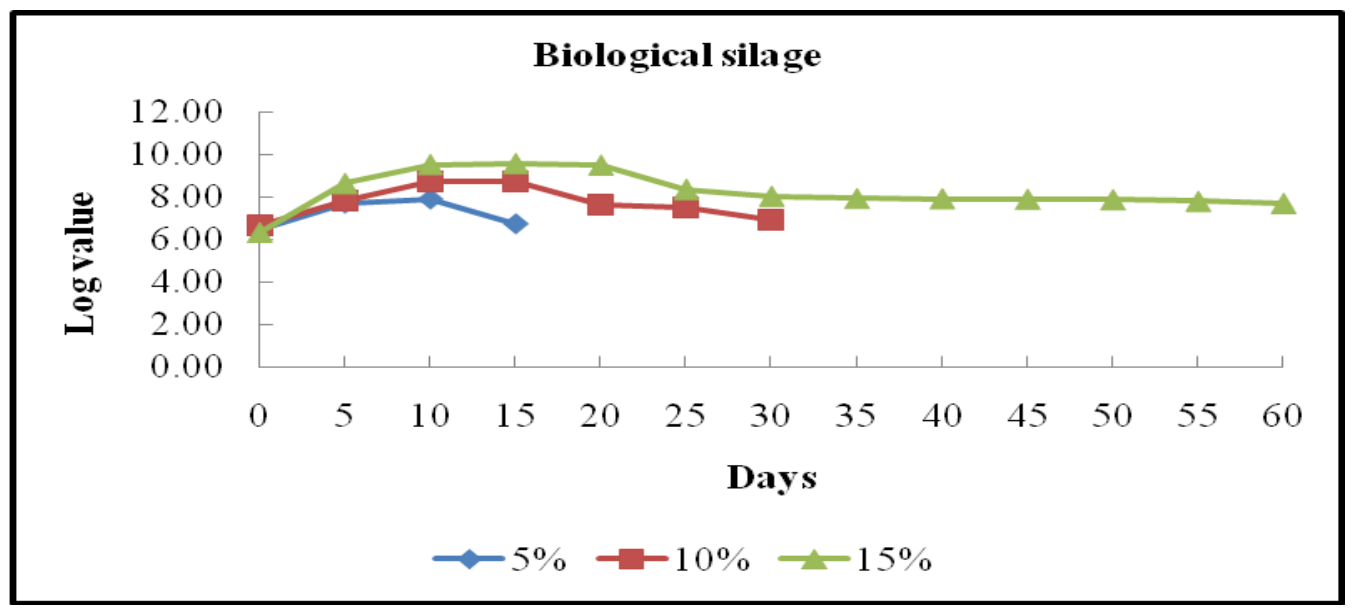

Table.1 Proximate composition of fish market waste

\begin{tabular}{|c|c|}
\hline Fish waste & Proximate composition (\%) \\
\hline Moisture & $77.09 \pm 0.14$ \\
\hline Crude protein & $15.20 \pm 0.15$ \\
\hline Fat & $4.03 \pm 0.07$ \\
\hline Ash & $3.30 \pm 0.11$ \\
\hline
\end{tabular}

Table.2 Chemical and microbiological analysis of fish market waste

\begin{tabular}{|c|c|}
\hline $\mathrm{pH}$ & 6.5 \\
\hline AAN $\left(\mathrm{mg}-\mathrm{N} 100 \mathrm{~g}^{-1}\right)$ & 10.66 \\
\hline TVB-N $\left(\mathrm{mg}-\mathrm{N} 100 \mathrm{~g}^{-1}\right)$ & 16.55 \\
\hline TPC $(\mathrm{cfu} / \mathrm{g})$ & $6.2 \times 10^{6}$ \\
\hline
\end{tabular}


Palekar (2009) reported similar value of TVB-N in formic acid silage increased from $18.22 \mathrm{mg}-\mathrm{N} 100 \mathrm{~g}^{-1}$ to $57.67 \mathrm{mg}-\mathrm{N} 100 \mathrm{~g}^{-1}$ at the end of $90^{\text {th }}$ day of storage.

\section{Biological silage}

In case of biological silage TVB-N value of treatments $\mathrm{C} 1, \mathrm{C} 2$ and $\mathrm{C} 3$ (Biological silage $5 \%, 10 \%, 15 \%$ ) were $22.73,22.17,19.83 \mathrm{mg}$ $\mathrm{N} 100 \mathrm{~g}^{-1}$ initially and which increased up to $57.35,39.43,33.55 \mathrm{mg} \mathrm{N} 100 \mathrm{~g}^{-1}$ at the end of $12^{\text {th }}, 24^{\text {th }}, 24^{\text {th }}$ day respectively. In treatment C3 (Biological silage $15 \%$ molasses) there was no changes in TVB-N value at the end of $60^{\text {th }}$ day. Faid et al., (1996) showed that TVN increased in trial 1 from $71.26 \mathrm{mg} \mathrm{N}^{2} 100 \mathrm{~g}^{-1}$ to reach $95.03 \mathrm{mg} \mathrm{N} 100 \mathrm{~g}^{-1}$ after1 day and

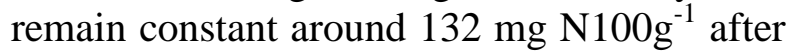
15 days of fermentation at $22^{\circ} \mathrm{C}$. The initial TVB-N of CS (Curd silage) was $20.13 \mathrm{mg}-\mathrm{N}$ $100 \mathrm{~g}^{1}{ }^{1}$ which increased up to $133.28 \mathrm{mg}-\mathrm{N}$ $100 \mathrm{~g}^{-1}$ at the end of $90^{\text {th }}$ day reported by Palekar (2009) (Fig. 9).

\section{Total Plate Count (TPC)}

In, biological silage treatments $\mathrm{C} 1, \mathrm{C} 2, \mathrm{C} 3$ (Biological silage 5, 10, 15\%) shown TPC $3.16 \times 10^{6}, 2.74 \times 10^{6}, 4.50 \times 10^{6} \mathrm{cfu} / \mathrm{g}$ initially. In the present study TPC were decreased during storage. In Treatment C2 (Biological silage 10\%) TPC was decreased and then increased after 24 days. If sufficient carbohydrate is not present in the medium, required levels of acid will not be produced, as results of putrefying bacteria increased. The last measured TPC in C3 (Biological silage $15 \%$ ) was $8.20 \times 10^{3} \mathrm{cfu} / \mathrm{g}$ at the end of $60^{\text {th }}$ day. Ozyurt et al., (2015) observed slightly similar result. Similar results were depicted by Palekar (2009), Rahmi et al., (2008). Bello et al., (1993) studied bacterial fish silage produced from several fish species mixed with molasses, fruits sorbate (pineapple and papaya) and starter culture of
Lactobacillus plantarum. It was found that the bacterial silage showed only few aerobic mesophilic organisms due to the low $\mathrm{pH}$ values and the development of LAB (Fig. 10).

\section{Lactic Acid Bacteria (LAB)}

In biological silage $\mathrm{C} 1, \mathrm{C} 2$ and $\mathrm{C} 3$ (Biological silage 5, 10, 15\%) initial LAB count were $2.73 \times 10^{6}, 4.70 \times 10^{6}, 2.24 \times 10^{6}$ cfu/g respectively. A sharp increase in LAB count was observed after fermentation shown in (Table 2 and Fig. 11). The last measured LAB in treatment C3 (Biological silage 15\%) was $5.10 \times 10^{7} \mathrm{cfu} / \mathrm{g}$ at the end of 60 th day. During storage study there was increase in LAB were observed initially and then gradually decreased up to end of storage. But at a certain stage LAB count was decreased due to depletion in carbohydrate sources. Total LAB counts of silage at maximum bacterial growth in this study were similar to the results reported by Palekar (2009), Zahar et al., (2002) and Ozyurt et al., (2015).

\section{Changes in proximate composition}

\section{Protein}

In the present study results of protein content in the present experiment showed significantly decreased with respect to increase in concentration of acid as well as increase in experimental duration. During the initial day of the experiment, the average crude protein content recorded was $15.20 \%$. But at the end of the experiment, a fall in protein level was noticed with considerable level of $13.11 \%, 12.91 \%$ in treatments A2, A3 (3.5 and $4.5 \%$ sulphuric acid) ensilages, $13.03 \%, 12.82 \%$ in B2 and B3 (3.5 and 4.5\% formic acid ensilages) and $14.72 \%$ in treatment C3 (15\%molasses) respectively at the end of 60 days. Reduction of protein content in the ensilage may be due to break down of protein (FAO, 2007). Vidotti et al., 
(2003) observed a reduction in crude protein level in combined (2\% each of formic acid and sulphuric acid) fermented silage of tilapia filleting residue when compared to nonfermented tilapia filleting residue. Ramasubburayan et al., (2013) and Palekar (2009) reported similar results were that at end of the experiment, a fall in protein level was noticed.

\section{Fat}

The fat content in the present study revealed that at the beginning of the experiment, it was an average $4.03 \%$ in concentrations of sulphuric acid, formic acid, and biological silages. But when the experimental days prolonged, the lipid content increased at the end of the experiment, the increase in lipid content were $5.06 \%, 5.24 \%$ in treatments A2 and A3 (3.5 and $4.5 \%$ sulphuric acid silages), $5.02 \%, 5.46 \%$ in B2 and B3 (3.5 and $4.5 \%$ formic acid silages) and 4.54 in $\mathrm{C} 3$ (biological silage with $15 \%$ of molasses) respectively. In the present study the continuous increase in lipid content during storage period may be due to release of fats from raw material Dapkevicius et al., (1998) reported $3.6 \%$ increase in lipid content from 11.3 to $14.9 \%$ from initial to final stage (15 days) of storage of $3 \%$ formic acid ensilage of blue whiting. The lipid content was between 8.08 and $8.27 \%$ in $2,2.5,3 \%$ concentrations of formic acid silages but at the end of the experiment, the increase in lipid content increased between up to 10.66 and 12.24 respectively in the 2, 2.5, $3 \%$ concentrations of formic acid silages on dry matter basis reported by Ramasubburayan et al.,(2013), Palekar (2009).

\section{Moisture}

In present study found that significant decrease in moisture content of silages. The initial moisture content recorded was $77.09 \%$.
But at the end of the experiment, a significant decrease in moisture level was noticed with considerable level of $75.24 \%, 75.54 \%$ in treatments A2 and A3 (3.5 and 4.5\% sulphuric acid ensilages); $75.32 \%, 75.49 \%$ in B2 and B3 (3.5 and 4.5\% formic acid ensilages) and 73.62 in C3 (biological silage $15 \%$ molasses) respectively. Biological silage shown higher decreased in moisture level compared to acid level. This may be addition of lactic acid bacteria source such as curd might have increased the solid matter and decreased the moisture level. Ozurt et al., (2015) observed moisture content was decreased in all silages (Formic acid, Formic acid + Sulfuric acid, and streptococcus thermophiles) except Lactobacillus plantarum. Fermented silage showed lesser amount of moisture than acid silage. Palekar (2009) reported moisture content was decreased during storage in formic acid silage, Lactobacillus plantarum silage and curd silage after 90 days of storage.

\section{Ash}

Result of ash content in the present experiment found that significant decrease in ash content of the silage with respect to increase in acid concentration. During the initial day of the experiment, the average ash content recorded was $3.30 \%$. But at the end of the experiment, increase in ash level was noticed with considerable level of 5.12, 4.84 $\%$ in $\mathrm{A} 2$ and $\mathrm{A} 3$ (3.5 and $4.5 \%$ sulphuric acid silages); 5.03, $4.72 \%$ in B2 and B3 (3.5 and $4.5 \%$ formic acid silages) and $5.89 \%$ in $\mathrm{C} 3$ (biological silage with $15 \%$ molasses) respectively. Ozurt et al., (2015) reported ash content was increased in all silages (Formic acid, Formic acid + Sulfuric acid, Lactobacillus plantarum and streptococcus thermophiles). Neethiselven et al., (2002) depicted ash in curd, Lactobacillus plantarum and FC silages 4.39, 3.37 and $3.35 \%$ respectively. Babu et al., (2005), Palekar 
(2009) observed that ash content was higher in fermented silage than acid silage

In present study found that fish silage is ecofriendly to the environment, safer, technologically simple and more economical than the manufacture of fish meal. Today, silage technology is most useful for solving the waste problem from industry and fish market. Fish silage would be a good potential source for animals in arid regions as it contained high protein (Al-Abri et al., 2014; Pagarkar et al., 2006; Palekar, 2009). In all three methods of fish silage production (mineral acid, organic acid and biological method), the optimum amount of sulphuric acid, formic acid and molasses were determined $3.5 \%, 3.5 \%$ and $15 \%$ respectively.

\section{Acknowledgements}

This paper forms the part of master dissertation of Nikhil D. Palkar. The authors are thankful to Associate Dean, College of Fisheries, Shirgaon, Ratnagiri for providing necessary facilities to carry out research work.

\section{References}

Abowei, J. F. N. and Tawari, C. C. (2011) Some basic principles of fish processing in Nigeria. Asian Journal of Agricultural Sciences, 3(6):437-452

Ahmed, J. and Mahendrakar, N. S. (1996a) Autolysis and rancidity development in tropical freshwater fish viscera during fermentation. Bioresource Technol., 58:247-251

Al-Abri, A. S., Mahgoub, O., Kadim, I. T., Al-Marzooqi, W., Goddard, S. J. and Al- Farsi, M. (2014) Processing and evaluation of nutritive value of fish silage for feeding omani sheep. Journal of Applied Animal Research, 42 (4): 406-413

Anon, (1999) Lamerenchiffres. Ministere des
Peches Maritimes. Royaume du Maroc. AOAC, (2005) Official methods of analysis, $18^{\text {th }}$ edition, Association of Official Analytical Chemists, Washington, Arlington, Virginia, USA.

APHA, (1992) Compendium of methods of the microbiological examination of foods. M. L. Speck, (Ed). APHA, Publication, Washington, U.S.A.

Babu, U. S. J., Rao, B. M., Kasim, D. I. and Nair, K. G. R. (2005) Biochemical and microbiological quality of Formic acid silage and lactobacillus fermented silage. Fishery Tech.42 (2): 163-170

Beatty, S. A. and Gibbons, N. E. (1937) The measurement of spoilage in fish. J. Biol. 3:77-81

Bello, R., Cardillo, E. and Martinez, R. (1993) Microbial silage production from eviscerated fish. Arch LatinoamNutr. 43:221-227

Benjakul, S. and Morrissey, T. (1997) Protein hydrolysate from pacific Whiting Solid wastes. J. Agriculture., Food Chem, 45: 3423-3430

CMFRI, (2015) Central Marine Fisheries Research Institutes. Department of Agricultural Research and Education Government of India, Kochi.

Dapkevicius, M. L. E., Batista, I., Nout, M.J.R., Rombouts, F.M. and Houben, J. H. (1998) Lipid and protein changes during the ensilage of blue whiting (Micromesistius poutassou Risso) by acid and biological method. Food chemistry, 63(1): 97-102

Disney, J.G., Tatterson, I. N. and Oley, J. (1977) Recent development in fish silage In: proceedings of the conference on the handling, processing and marketing of tropical fish. London: 273275

Djazuli, N., Sunarya and Dwi Budiyanto (2007) Utilization of fish waste for fish silage powder and its application as feed for chicken and fish culture. National 
Center for quality Control and Processing Technology Development, Directorate General of fisheries, JI. MuaraBaru Ujung Penjaringan, Jakarta 14440, Indonesia pp.131-143

DOF, (2013). National Fish Week (2013) Compendium (in Bengali). Department of Fisheries, Ministry of Fisheries and Livestock, Dhaka, Bangladesh. pp.144

Espe, M. and Lied, E. (1999) Fish silage prepared from different coocked and uncooked raw materials: Chemical changes during storage at different temperatures. Journal of the science of food Agriculture, 79: 327-322

Faid, M., Zouiten, A., Elmarrakchi, A. and Achkari-Begdouri,

A.

(1996)

Biotransformation of fish waste into a stable feed ingredient. Food chemistry, 60(1) $13-18$

Faid, M., Zouiten, A., Elmarrakchi, A. and Achkari-Begdouri,

A.

(1996)

Biotransformation of fish waste into a stable feed ingredient. Food chemistry, 60(1) 13-18

FAO (2007) Animal feed resources information system. http:// www.fao.org.

Gullu, K., Guzel, S. and Tezel, R. (2015)Producing silage from industrial waste of fisheries. Muglasitki Kocman University, Faculty of Fisheries, 48000, Mugla, Turkey, Ekoloji24 (95): 40-48

Haaland, H. and Njaa (1989) Total volatile nitrogen- A quality criterion for fish silage. Aquaculture 79 (1-4): 311-316

Hanafy, M. A. and Ibrahim, S. M. (2004) Storage stability of yogurt fermented fish silage. Journal of Egyptian Academic Social and Environmental Development, 5:23-41

Hasan, B. (2003) Fermentation of fish silage using Lactobacillus pentosus. Journal Nature Indonesia 6 (1):11-15

Hassan, T. E. and Heath, J. L. (1987) Chemical and nutritional characteristics of fish silage produced by biological fermentation. Biological Wastes 20:187201

Huisman, E. A., Zonneveld, N. and Boumonus, A. H. M.(1989) Proceedings of the Asian Seminar on Aquaculture, Malang, Indonesia, 14-18 November, $1988 . \quad$ Pudoc, Wagenigen.pp.138-146N

Kompiang, I. P., Yushadi and Creswell, D.C. (1979) Microbial Fish silage: Chemical position Fermentation characteristic and nutritional value. In proc, I. P.F.C. Workshop fish silage, FAO F. Fish report, No. 230:105

Martin, A. M. (1996) Lactic acid fermentation- aided biomass conversion, in lactic acid bacteria. Current advance in genetics, Metabolism and application, NATO ASI Series H. Cell biology, Berlin, Spinger- Verlag, 98: 942-945

Mousavi, S.L., Mohammadi, G., Khodadadi, M. and Keysami, M. A. (2013) Silage production from fish waste in cannery factories of Bushehr city using mineral acid, organic acid, and biological method. International Journal of Agriculture and Crop Sciences,6 (10): 610-616

Neethiselvan, N., Jasmine, G. I. and Jayasekaran, G. (2002) Lactic acid fermentation of minced meat of Leiognathus splendens (cuvier,1829) using different bacterial sources. Fishery Technology, 39 (2):129-136

Ozyurt, G., Gokdogan, S., Simsek, A., Yuvka, I., Erguven, M. and Boga, E. K. (2015) Fatty acid composition and biogenic amines in acidified and fermented fish silage: a comparison study. Journal of Animal Nutrition 1-15

Pagarkar, A. U., Basu, S., Mitra, A. (2005)An evaluation of the suitability of croaker fish (Otolithus sp.) waste product silages in feed Macrobrachium 
rosenbergii. Biosciences, Biotechnology

Research Asia, 3(2):297-306

Pagarkar, A. U., Basu, S., Mitra, A. and Sahu, N. P.(2006) Preparation of biofermented and acid silage from fish waste and its biochemical characteristics. Asian Jr. of Microbiol. Biotech. Env.Sci., 8(2):381-387.

Palekar, (2009) Transformation of fish waste into silage using Lactic Acid Bacteria. Submitted to B.S.K.K.V.Dapoli,1-115

Raa, J., and Gilberg, A., (1982) Fish silage: a review. Journal of the Food Science and Nutrition 61: 383-419

Raghunath, M.R., and Mccurdy, A.R. (1990) Influence of $\mathrm{pH}$ on the proteinase complement and proteiolytic products in rainbow trout viscera silage. J. Agri. Food chem, 38: 45-50

Rahmi, M., Faid, M., Yachioui, E. M. Berny, E.H., Fakir, M. and Ouhssine, M. (2008) Protein rich ingredients from fish waste for sheep feeding. African Journal of Microbiology Research, 2:73-77

Ramasubburayan, R., Iyapparaj, P., Subhashini, K. J.,Chandran, M. N., Palavesam, A. and Immanuel, G.(2013) Characterization and nutritional quality of formic acid silage developed from marine fishery waste and their potential utilization as feed stuff for common carp (Cyprinus carpio) fingerlings. Turkish Journal of Fisheries and
Aquatic Sciences 13: 281-289

Snedecor, G. W. and Cocharn, W. G., (1967) In 'Statistical methods' p.593, oxford and IBM publishing co., New Delhi.

Stone, F. S., and Hard, R. W. (1986) Nutritional value of acid stabilized silage and liquefied fish protein. $J$. of food Agric., 37: 797

Tanuja, S., Mohanty, P. K., Kumar, A., Moharana, A. and Nayak, S. K. (2014) Shelf life study of acid added silage produced from fresh water fish dressing waste with and without the addition of antioxidants. International Journal of Agriculture and Food Science Technology, 5(2):91-98

Tatterson, I. N. and Windsor, M. L. (1974) Fish silage. Journal of the Science of Food and Agriculture 25 : 369-379

Vidotti, R. M., Viegas, E. M. M. and Carneiro, D. J. (2003) Amino acid composition of processed fish silage using different raw materials. Animal Feed Science and Technology 105:199204

Zahar, M., Benkerroum, N., Guerouali, A., Laraki, Y. and El-Yakoubi, K. (2002) Effect of temperature, anaerobiosis, stirring and salt addition on natural fermentation silage of sardine and sardine wastes in sugarcane molasses. Bioresource Technology 82: 171-176

\section{How to cite this article:}

Nikhil D. Palkar, J.M. Koli, S.B. Patange, S.T. Sharangdhar, R.K. Sadavarte and Sonavane A.E. 2017. Comparative Study of Fish Silage Prepared from Fish Market Waste by Using Different Techniques. Int.J.Curr.Microbiol.App.Sci. 6(12): 3844-3858. doi: https://doi.org/10.20546/ijcmas.2017.612.444 